\title{
A Venetian edition of Avicenna's works owned by Lonicer: Part 2
}

In Part I of this article' I described the text volume of the Library's copy of Avicenna's works ${ }^{2,3}$ which was published in Venice in 1555 and purchased by the botanist and physician Adam Lonicer at the spring Frankfurt fair of 1556. Here I shall consider the Index volume that accompanies the text, and the binding of both volumes and say a little about the importance of the Frankfurt Book Fair in Renaissance Europe.

\section{The index volume}

The 1555 edition of Avicenna's works must have been a success since, in 1557, the publisher issued a comprehensive index to its contents whose compilation must have been a considerable undertaking. The titlepage says that it is particularly intended to provide a reference to the effects of medicaments 'both simples and compounds' on the human body.

The index is sophisticated in the way in which it indicates the exact location

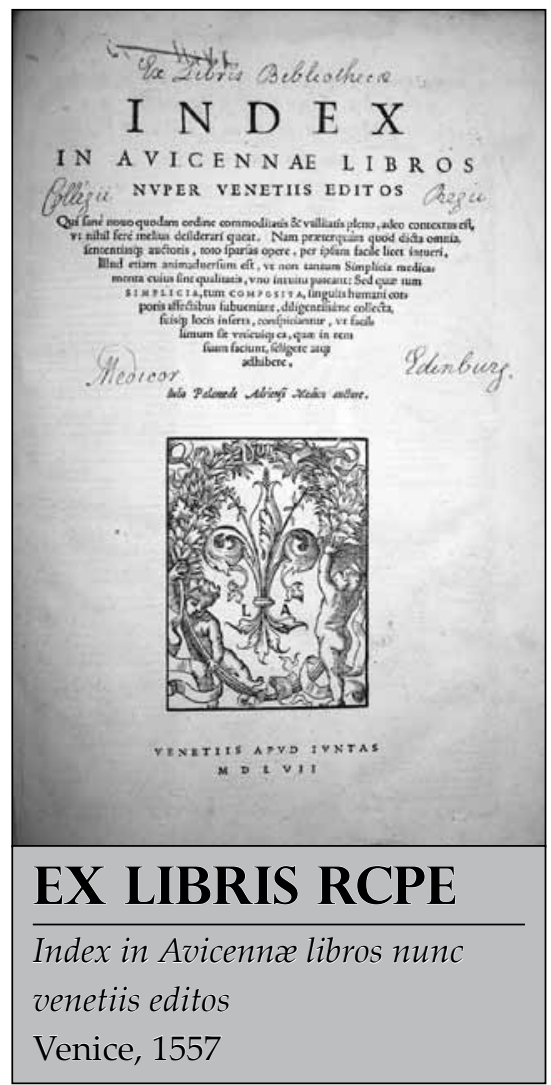

respiration and finally death. Line 10 effectively repeats what the index entry says about the fatal dose. This passage also demonstrates the many references to other authorities that the commentators inserted. The superscript letters in the text refer to abbreviated references in the margin; Dioscorides, Haly Abbas, Rhases and Galen are all referred to in the passage in Figure 2.

\section{The binding and related matters}

The binding is interesting. ${ }^{\dagger}$ The books are in their original bindings of tawed pigskin over wooden boards elaborately decorated with blind stamps and roll-tools and fitted with bronze clasps to hold them closed. The index volume is bound to match the text, but with different roll-tool decorations and a rather more elaborate design; it also is fitted with clasps which are still in working condition. The roll-tool decorations are of two types, simple borders and strips of pictures of biblical figures of the reference in the text. It should be explained that the 1555 text is foliated not paginated; that is, the leaves and not the pages are numbered; a number appears at the top right corner of the recto of each leaf, that is, the corner that appears on the right of the book opening. The text on the recto of each leaf is divided into four equal blocks marked by the letters $A$ to $D$ and that on the other side of the leaf (verso) is marked $\mathrm{E}$ to $\mathrm{H}$. The lines of text can then be referred to by numbers counting down the page from one of the letters. This was not an uncommon arrangement in the sixteenth century for ease of reference to large printed pages. As an example of how the system works, Figure I shows part of the index entry for opium which includes three references to folium 493 section $\mathrm{H}$. The first index entry, to line seven, translates as 'The toxic effects of opium'. The first reference to line 10 says: 'Opium is fatal in a dose of two drachms and kills in two days; and its maximum effect occurs when given in wine.'The second reference is: 'Treatment of opium's toxic effects.' Figure 2 shows the relevant part of the verso of folium 493 of the text. The capital $\mathrm{H}$ in the right margin is the letter referred to in the index. The line count begins with the heading of Cap. I as line I; Summa tertia de medicinis, quae sunt ex plantis venenosis frigidis. (The third section on drugs from cold poisonous plants.) Line 7 describes the toxic effects of opium including deep sleep, slurred speech, stertorous with cartouches containing phrases from Latin quotations from the Vulgate below them. The text volume has one roll of figures which carries the letters $\mathrm{EH}$; its other two rolls are just simple borders. The index volume is decorated with four roll-tools two of which carry biblical figures. The wider of these was applied four times to form a frame near the edges of the board; it carries the letters TD and the date 1560 on an image of Christ on the cross, and in the next panel below, the monogram NP.This roll identifies ${ }^{5}$ the binder as Thomas Drechsler of Frankfurt who became

\section{N D E X}

Opium qux nocumenta inferat $4993+\mathrm{H}, 7$ Opium interficit ad pondus duarum drag, marum $\&$ interficit duobus diebus $\delta$ ma xime dando cum vino. $\quad 493+\mathrm{H} .10$ Opn̈nocumenti cura. $\quad 493$. H.10 $\int$ Opio poto, Fiftula paltoris, id eft alifma $\begin{cases}\text { fue damafonia. } & 126 . C_{*} 4 \\ \text { Acetum. } & 107 . D_{*}\end{cases}$ FIGURE I Part of the entry in the index volume (I557) for opium. The format of the entries is: folium number + index letter $(A-H)$ + line number counting down from the index letter. 


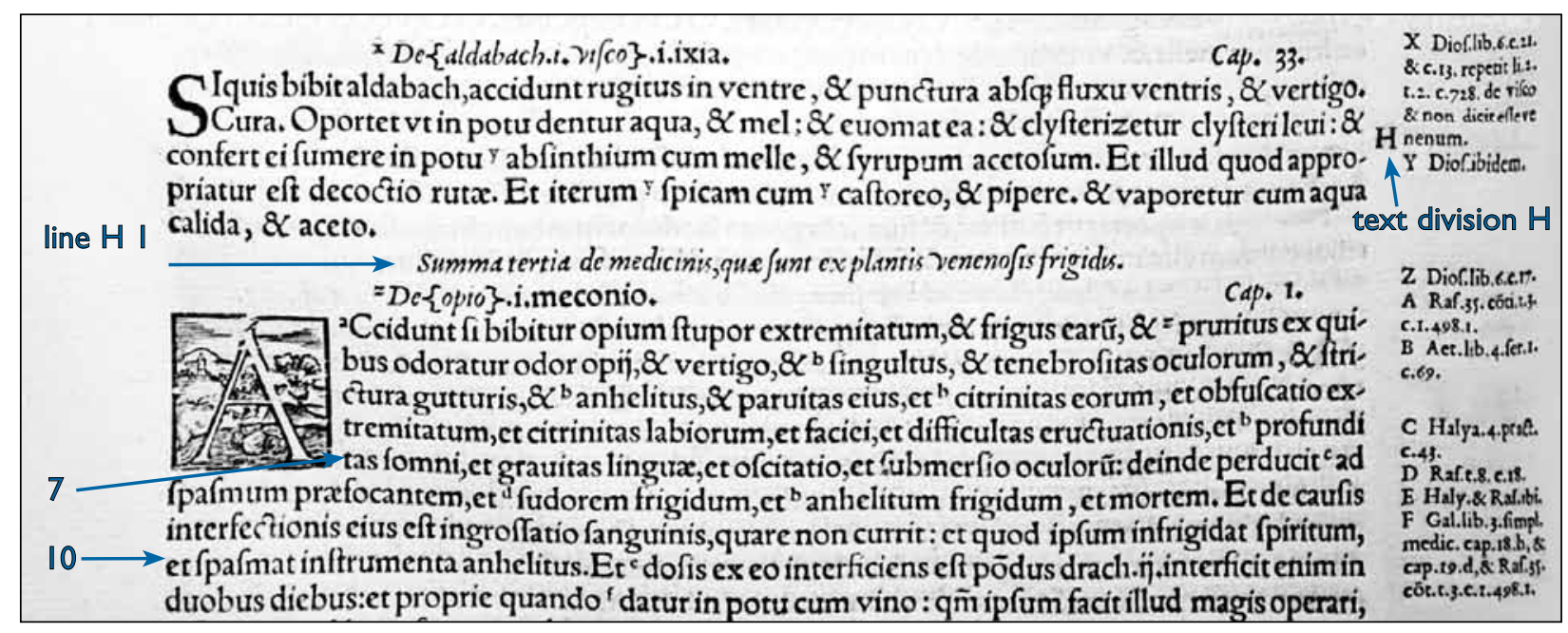

FIGURE 2 Part of the verso of folium 493 of the text volume (I555) showing the last index section of text, $\mathrm{H}$, annotated to explain the system of reference. The lines of section $\mathrm{H}$ are counted down from the heading of the start of $\mathrm{Cap}$. I, Summa tertia de medicinis... as line I. There are comments on actions of opium in lines 7 and I0.

a Burger and independent Master in 1560 following his marriage to the widow of the printer Cyriacus Jacob. The monogram NP on the same roll-tool is fairly certainly that of the engraver of the roll-tool. Tools marked NP were used by a number of different book binders and came in various designs. I have not been able to identify the binder who used the $\mathrm{EH}$ roll on the text volume however.

Since the binding and paste-downs of both volumes are original and Lonicer's notes on the paste-down and endpaper of the text volume are dated August 1558, this volume must have been bound before that date. The index volume was not published until 1557 and we do not know when Lonicer bought it (presuming it was also his - it is not annotated). It was bound in Frankfurt by Thomas Drechsler not earlier than 1560. It seems likely that Drechsler bound it to match the text volume in general style, though the details of the design are different and use different roll-tools, as we have seen. The work of both Drechsler and the unknown $\mathrm{EH}$ binder is of very high

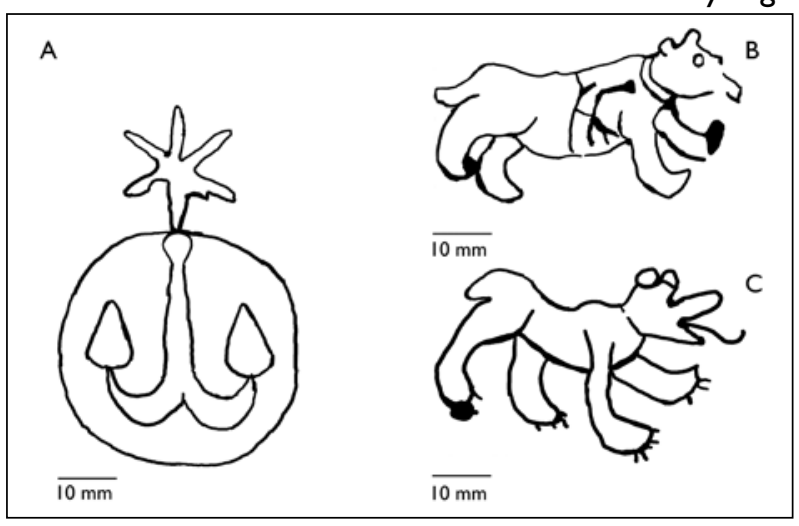

FIGURE 3 Watermarks. (A) Anchor with star;Avicenna, text, 1555. Venetian paper mill. (B) Bear with harness; front end-paper, Avicenna text 1555. (C) Bear;'padding' paper of Index Avicennæ, I557. (B and C) are from the paper-mill at Thal near Berne. quality and both bindings are still in good condition though the text volume has suffered worm attack at some time. The index volume is undamaged, however, and both of its bronze clasps are still in excellent working order.

More than half the bulk of the index volume is made up of blank sheets of paper.The watermarks ${ }^{\text {tt }}$ of the paper allow us to draw some further conclusions about the construction of the volumes. In the paper of the title-page of the text volume we find the watermark of Figure $3 \mathrm{~A}$, an anchor in a circle surmounted by a star. This identifies the paper as from a Venetian paper-mill - as one would expect from a Venetian printer. But the paper making up the endpapers of the text volume is notVenetian, it is from the mill at Thal near Berne and carries one of the many variants of the bear that distinguishes paper from that mill, (Figure 3B). The paper used to pad out the index volume is also from Thal and carries a different bear (Figure $3 \mathrm{C}$ );

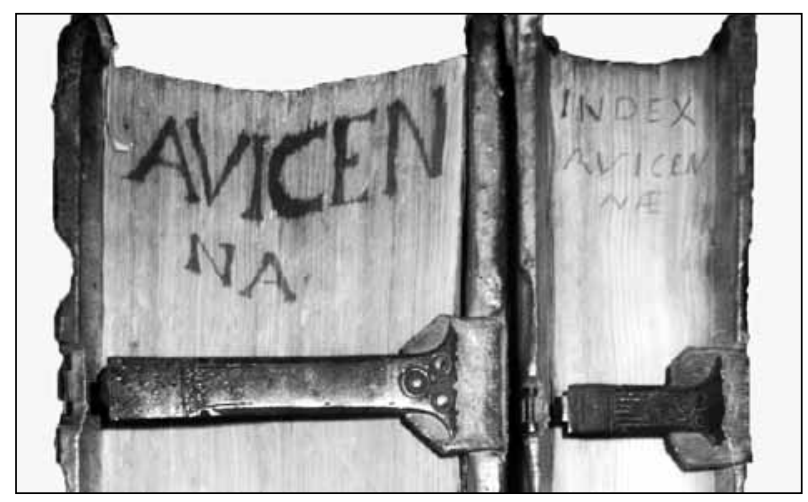

FIGURE 4 Fore-edges of the two volumes. Left: the text volume with 'Avicenna' written in ink on the edges of the pages. Right: The index volume carries 'Index Avicennæ' in ink. This shows that the volumes were once shelved with the fore-edges out. Note the bronze clasps to hold the books closed; these are the upper clasps of a pair on each volume. The letters in the right image have been retouched to improve their legibility. 
this padding paper is thicker than the paper used for the letterpress of either volume (about $0.23 \mathrm{~mm}$ compared to $0.13-0.15 \mathrm{~mm}$ ) and has a rougher surface. It seems that the binder padded out the printed sheets to make a volume about twice as thick as it would otherwise have been; perhaps this was to produce a book that would not look ridiculously thin standing beside its substantial companion? The EH binder also used Swiss paper to form the endpapers of the text volume of I555. All of this is entirely consistent with the binding of the text volume also being carried out in or near Frankfurt as its style suggests, and not in Venice. This all accords with the usual practice of books being sold as unbound bundles of sheets which the buyer then had bound into volumes according to his taste - and the depth of his purse.

We know that these two books originally stood on the shelf with the fore-edge out - that is, with the spine to the back, the opposite way to how we now shelve books. We can tell this because the fore-edges of the volumes have their short titles written in ink on the exposed edges of the sheets (Figure 4). The older practice of keeping books lying flat in chests had given way to storing them on shelves by the mid sixteenth century. But we can see that, later, these copies were stored spine-out since remains of the titles written in ink are visible at the top of the spines (see Figure 2 of Part I of this article).The red leather labels with gold titles were added later still and are pasted on to the original spine.

\section{The Frankfurt book fairs}

The book fairs in Frankfurt were established in the fifteenth century; ${ }^{6}$ though they gave way to the Dresden fairs in the eighteenth century they were revived after the Second World War and still continue. Frankfurt was already a major commercial centre in the fifteenth century with well-established bankers and a major industry in money changing. The date of the first book fair is uncertain but it seems already to have been established by 1462 when Johann Fust and Peter Schöffer are said to have gone there and sold copies of their works produced by the then very new process of printing from movable type ${ }^{6}$. Fust was Gutenberg's former partner and financial backer and Schöffer, by now Fust's son-in-law, was Gutenberg's assistant or foreman. By the mid-sixteenth century there were two book fairs in Frankfurt each year, in spring and in autumn, and these provided one of the principal means of book exchange across Europe. Printers and publishers brought their books to Frankfurt and sold or exchanged them with other dealers; they also acted as agents for their clients at home, seeking and purchasing copies of particular works to order. All this, of course, in addition to selling directly from their booths at the fair.
In the early era of the fair the sale of books in Frankfurt seems to have been confined to the period of the fair itself and the hours of business were strictly regulated. In spite of these restrictions, the Frankfurt fair was the occasion on which a great deal of the printers' annual sales were made and, by the sixteenth century, printers and their agents were coming to Frankfurt from all European countries. For example, Christophe Plantin, whose printinghouse in Antwerp would become the largest in Europe, visited the Lent (spring) fair in 1566 - his accounts for that visit survive - and André Wechel, one of the best Parisian printers, visited the fair frequently from Paris before he fled to Frankfurt permanently after the massacre of St. Bartholomew's Eve in 1572; he was almost certainly a Protestant and narrowly escaped with his life. Catalogues of the books on sale were produced as a private venture from I564 and, from 1598 until 1750, the Frankfurt city council issued an official catalogue. In addition, regular newsletters (relationen) with news of all kinds - not only about the fairs - were issued twice a year from I59| until 1806. ${ }^{6}$ The Frankfurt fairs were undoubtedly the principal hub of the European international book trade in the sixteenth century and Lonicer, who became a publisher in Frankfurt after his marriage to Egenolff's widow (see the first part of this article), must have been well placed there to sell his books.

IML Donaldson, Honorary Librarian, RCPE (email: i.m.l.d@ed.ac.uk)

\section{NOTES}

t Images of the binding with further details are available at www.rcpe.ac.uk/library/ex_libris/avicenna.html

tt Watermarks. The main authority for the identification of watermarks before 1600 is the monumental work of Briquet (ref. 4). The anchor mark in the 1555 volume (Figure 3A) is in Briquet's group 477-532 and is certainly from a Venetian mill (Briquet, Text vol I, p. 40). The bear in the padding paper of the 1557 index volume (Figure $3 \mathrm{C}$ ) is Briquet's number 12279 and the other bear (with collar and harness, Figure 3B) in the end-paper of the 1555 text volume is of the same group which contains many variants. Though this second mark of a bear with a collar and harness is not illustrated by Briquet, its paper was certainly made by the mill in Thal (see Briquet, Text vol II, p. 617).

\section{REFERENCES}

I Donaldson, IML. A Venetian edition of Avicenna's works owned by Lonicer: Part I.J R Coll Physicians Edinb 201 I;41:|82-84.

2 Avicenna. Avicennæ Liber canonis, De medicinis cordialibus, et Cantica iam olim quidem a Gerardo Carmonensi ex arabico sermone in latinum conversa... Trans. Andrea Alpago; ed. Benedetto Rinio. Venice: apud luntas; 1555.

3 Index in Avicennæ libros nuperVenetiis editos...Venice: apud luntas; 1557.

4 Briquet, C-M. Les filigranes; dictionnaire historique des marques du papier dès leur apparition vers 1282 jusqu'en 1600. A facsimile of the 1907 ed. with supplementary material contributed by a number of scholars. 4 vols. Edited by Allan Stevenson. Amsterdam: Paper Publication Society; 1968.

5 Haebler, K. Rollen-und Plattenstempel des XVI. Jahrhunderts. Sammlung bibliothekswissenschaftlicher Arbeiten; 4I-42. Leipzig: Harrassowitz; 1928. p. 94; p. 34I.

6 Weidhaas PA. History of the Frankfurt Book Fair.Trans. Gossage, CM, Wright, W.A. Toronto: Dundurn Press; 2007. 